\title{
Opioid Receptor Modulation of a Metabolically Sensitive Ion Channel in Rat Amygdala Neurons
}

\author{
Xueguang Chen, Hector G. Marrero, and Jonathan E. Freedman \\ Department of Pharmaceutical Sciences, Northeastern University, Boston, Massachusetts 02115
}

\begin{abstract}
We have used single-channel patch-clamp recordings to study opiate receptor effects on freshly dissociated neurons from the rat amygdalohippocampal area (also called the posterior nucleus of the amygdala), an output nucleus of the amygdala implicated in appetitive behaviors. Dissociated cells included a distinct subpopulation that was $30-40 \mu \mathrm{m}$ in diameter, multipolar or pyramidal in shape, and immunoreactive for neuronspecific enolase, $\mu$ opioid receptors, and galanin. In whole-cell perforated-patch recordings, these cells responded to low concentrations of $\mu$ opioid agonists with a hyperpolarization. In cell-attached single channel recordings, these cells expressed a large variety of $\mathrm{K}^{+}$-permeable ion channels, including 20-100 pS inward rectifiers and 150-200 pS apparent $\mathrm{Ca}^{2+}$-activated $\mathrm{K}^{+}$channels, none of which appeared sensitive to the presence of opioid drugs. In contrast, a 130 pS inwardly rectifying channel was selectively activated by $\mu$ opioid receptors in this same
\end{abstract}

subpopulation of cells and was active only in the presence of opioid agonists, and inhibited in the presence of antagonists. Channels identical to the $130 \mathrm{pS}$ channel in conductance and voltage sensitivity were activated in the absence of opioids, when the cells were treated with glucose-free medium or with the metabolic inhibitor rotenone. The sulfonylurea drug tolbutamide inhibited $130 \mathrm{pS}$ channel openings elicited by opioids. Thus, a subpopulation of amygdala projection neurons expresses a metabolically sensitive ion channel that is selectively modulated by opiate receptors. This mechanism may allow opioid neurotransmitters to regulate ingestive behaviors, and thus, opiate drugs to influence reward pathways.

Key words: amygdala; patch-clamp; potassium channel; opiate receptor; opioid receptor; galanin; sulfonylurea; addiction; satiety
Paradoxically, propensity to drug addiction is more prevalent than might be expected for an evolutionarily undesirable behavior. It is widely thought that this observation might be explained by the ability of drugs of abuse to influence reward pathways of behaviors that are needed for survival, such as feeding and reproduction. The amygdala is a limbic brain region implicated in some of the motivational aspects of opiates and other drugs of abuse (Koob et al., 1992; Breiter and Rosen, 1999). A study of the distribution of rat amygdala neurons expressing an inhibitory response to opiates in extracellular recordings in vivo found responses to be highly localized to two amygdaloid subnuclei, the central nucleus and the amygdalohippocampal area (AHA) (Freedman and Aghajanian, 1985), which are two major output nuclei of the amygdala (Pitkanen et al., 1997). Because the AHA presents a relatively uniform neuronal population to study, we have now used patch-clamp recordings from dissociated cells to examine the basis of the inhibitory opioid response of AHA neurons.

The AHA has also been called the posterior nucleus of the amygdala (Swanson and Petrovich, 1998) or the posterior portion of the medial nucleus (Konig and Klippel, 1963). It is a densely packed cell layer in the posteriomediodorsal amygdala, princi-

\footnotetext{
Received July 31, 2001; revised Sept. 12, 2001; accepted Sept. 12, 2001.

This work was supported by National Institutes of Health/National Institute on Drug Abuse Grant DA10086 (J.E.F.). We thank Pulin Patel for help with the immunocytochemistry.

Correspondence should be addressed to Dr. Jonathan E. Freedman, Northeastern University, 211 Mugar Building, 360 Huntington Avenue, Boston, MA 02115. E-mail: j.freedman@neu.edu.

H. G. Marrero's present address: Department of Physiology, University of Massachusetts Medical Center, Worcester, MA 01655.

Copyright (C) 2001 Society for Neuroscience $\quad 0270-6474 / 01 / 219092-09 \$ 15.00 / 0$
}

pally containing pyramidal or spindle-shaped projection neurons using glutamate as well as various peptides as neurotransmitters (Swanson and Petrovich, 1998). These peptides include galanin (Planas et al., 1994), and galanin release in the amygdala is known to regulate feeding behavior (Krykouli et al., 1990). Lesions near this area affect feeding and satiety (Rollins and King, 2000), and there is also evidence for an AHA role in sexual behaviors (Demas et al., 1997; Kondo et al., 1997; Petrulis and Johnston, 1999; Heeb and Yahr, 2000).

Several authors have suggested that opiate receptors may be coupled to ATP-sensitive $\mathrm{K}^{+}\left(\mathrm{K}_{\mathrm{ATP}}\right)$ channels (Ocana et al., 1990; Raffa and Codd, 1994; Shankar and Armstead, 1995; Kang et al., 1998; Lohmann and Welch, 1999; Rodrigues and Duarte, 2000). $\mathrm{K}_{\mathrm{ATP}}$ channels are regulated by intracellular levels of ATP, and therefore could confer on neurons the ability to detect brain glucose levels (Freedman and Lin, 1996; Seino, 1999). Thus, opioid receptor modulation of $\mathrm{K}_{\mathrm{ATP}}$ channels could be an attractive explanation of how opiates could affect satiety-reward pathways. However, there is little direct evidence for this idea in the brain; for instance, the ability of a $\mathrm{K}_{\mathrm{ATP}}$ channel blocker to inhibit an opiate effect does not demonstrate direct coupling of the receptor to the channel. We have recently described an inwardly rectifying $130 \mathrm{pS} \mathrm{K}+$-preferring cation channel in dissociated AHA neurons that is activated by $\mu$ opioid receptors in a membrane-delimited manner (Chen et al., 2000; Murphy and Freedman 2001). The gating of this channel changes after chronic morphine treatment in a manner that suggests that it may play a role in opiate tolerance (Chen et al., 2000). We now show that this channel is specifically expressed by a subset of cells that appear to be AHA projection neurons and that it is unique among the $\mathrm{K}^{+}$-permeable channels of these cells in its $\mu$ receptor sensitivity. 
We furthermore show that the same channel is metabolically sensitive.

\section{MATERIALS AND METHODS}

Cell preparation. Amygdala neurons were freshly dissociated by methods similar to those previously described (Greif et al., 1995; Chen et al., 2000). Male rats (Sprague Dawley VAF; Charles River Laboratories, Wilmington, MA), 30-45 d old, were killed by rapid decapitation, and the brains were rapidly and gently removed into an ice-cold solution of (in mM): $\mathrm{NaCl}, 124 ; \mathrm{KCl}, 4 ; \mathrm{CaCl}_{2}, 1 ; \mathrm{MgCl}_{2}, 1 ; \mathrm{MnCl}_{2}, 0.02$; D-glucose, 25; and PIPES-Na, 20, pH 7.0, equilibrated with $\mathrm{O}_{2}$. Coronal $300 \mu \mathrm{m}$ sections of the posteriodorsal amygdala were cut at $\sim 0^{\circ} \mathrm{C}$ on a vibrating tissue slicer. The slices were blocked mediodorsally with a scalpel blade to comprise an $\sim 1 \times 3 \mathrm{~mm}$ rectangle, including the AHA (Paxinos and Watson, 1986). One edge of the slice was located at the dorsal limit of the AHA, to completely exclude the ventral hippocampus; the cut defining the opposite edge was placed within the medial amygdala so that the slice would include the AHA and part of the regions of the amygdala, principally the cortical nucleus, immediately ventral to the AHA. After slowly warming the slices to $32^{\circ} \mathrm{C}$ while stirring continuously at $20-25$ rpm under $100 \% \mathrm{O}_{2}$, slices as needed for electrophysiology were treated with trypsin (type XI; Sigma, St. Louis, MO; 1000 benzoylarginine ethyl ester $\mathrm{U}$ in $0.5 \mathrm{ml}$ ) for $5 \mathrm{~min}$, followed by $0.125 \mathrm{mg}$ of soybean trypsin inhibitor for $2 \mathrm{~min}$. Slices were then washed with the above solution in which the $\mathrm{Ca}^{2+}$ concentration was reduced to $0.5 \mathrm{~mm}$ and triturated with a polished glass pipette. Cells were allowed to settle in a plastic Petri dish for $10 \mathrm{~min}$ and were generally used for recording within $1 \mathrm{hr}$. All recordings reported in this study were made from phase-bright cells, with bleb-free surfaces, and with preservation of some dendritic processes. For immunocytochemistry of dissociated cells, every cell with these morphological criteria was included in counts of cells for the presence or absence of labeling. Cellular diameter was estimated along the major somatic axis, using a calibrated eyepiece reticle.

Immunocytochemistry. Slices or dissociated cells were prepared as above, then fixed in $4 \%$ paraformaldehyde in PBS for $10 \mathrm{~min}$ at room temperature. They were then washed with $\mathrm{NH}_{4} \mathrm{Cl}, 0.5 \mathrm{mg} / \mathrm{ml}$ in PBS, followed by four washes of PBS. Incubations with antibodies were then made in PBS containing also $10 \%$ normal goat serum and $1 \mathrm{mg} / \mathrm{ml} \mathrm{NaN}_{3}$ (PBS-NGS). A rabbit polyclonal antibody to neuron-specific enolase was from Polysciences (Warrington, PA). A mouse monoclonal antibody to glial fibrillary acidic protein was from Chemicon (Temecula, CA), as were rabbit polyclonal antibodies to galanin, and to extracellular domains of $\mu, \delta$, and $\kappa$ opioid receptors. The opioid receptor antibodies were used at dilutions that were reported by the supplier to not cross-react with the other opioid receptor subtypes. Opioid receptor antibody incubations were each at 1:500 at room temperature overnight. Incubations with the antibodies to neuron-specific enolase (dilution 1:4000) or glial fibrillary acidic protein $(1: 400)$ were $1 \mathrm{hr}$ at $30^{\circ} \mathrm{C}$ and were preceded by cell permeabilization with $0.01 \%$ Triton X-100 in PBS for 1 min. In preliminary experiments, the galanin antibody was not active in fixed tissue, so it was used only in unfixed slices at $1: 1000$ at $4-8^{\circ} \mathrm{C}$ overnight. (Unfixed dissociated cells were not stable enough to label.) After primary antibody incubations, the cells or slices were washed four times with PBS-NGS, then incubated with fluorescent secondary antibodies at 1:300 in PBSNGS for $1 \mathrm{hr}$ at $30^{\circ} \mathrm{C}$. For glial fibrillary acidic protein, the secondary antibody was Alexa 488-conjugated goat anti-mouse $\mathrm{IgG}$; for all others, it was Alexa 546-conjugated goat anti-rabbit IgG, both from Molecular Probes (Eugene, OR). After five washes with PBS, fluorescence was viewed with a Nikon Diaphot microscope under mercury lamp illumination and fluorescein (for Alexa 488) or rhodamine (Alexa 546) filter sets. Control determinations of nonspecific fluorescence were made in each experiment by performing sham incubations omitting the primary antibody before treatment with the secondary antibody.

Electrophysiology. The dissociated cells were superfused at room temperature with (in $\mathrm{mm}$ ): $\mathrm{NaCl}, 149 ; \mathrm{KCl}, 3.5 ; \mathrm{CaCl}_{2}, 2.5 ; \mathrm{MgCl}_{2}, 1$; D-glucose, 10; and HEPES-Na, 10, pH 7.4, oxygenated and adjusted with sucrose to $330-340 \mathrm{mOsmol} / \mathrm{kg}$. Borosilicate glass patch pipettes had tip diameters of $1 \mu \mathrm{m}$. For whole-cell perforated-patch recordings, the pipettes were filled with (in $\mathrm{mM}$ ): $\mathrm{KCl}, 140 ; \mathrm{MgCl}_{2}, 5 ; \mathrm{HEPES}-\mathrm{K}, 10, \mathrm{pH}$ 7.2; gramicidin was used as the membrane-permeating agent (Rhee et al., 1994), and drugs were applied by change of solution from a constant-flow macropipette placed near the cell. For cell-attached single-channel recordings, the pipette solution was (in $\mathrm{mM}$ ): $\mathrm{KCl}, 140 ; \mathrm{CaCl}_{2}, 2.5 ; \mathrm{MgCl}_{2}$, 1; and HEPES-K, 10, $\mathrm{pH} \mathrm{7.4,} \mathrm{and} \mathrm{(except} \mathrm{for} \mathrm{rotenone,} \mathrm{which} \mathrm{was}$ applied via the external superfusion solution) drugs were added within
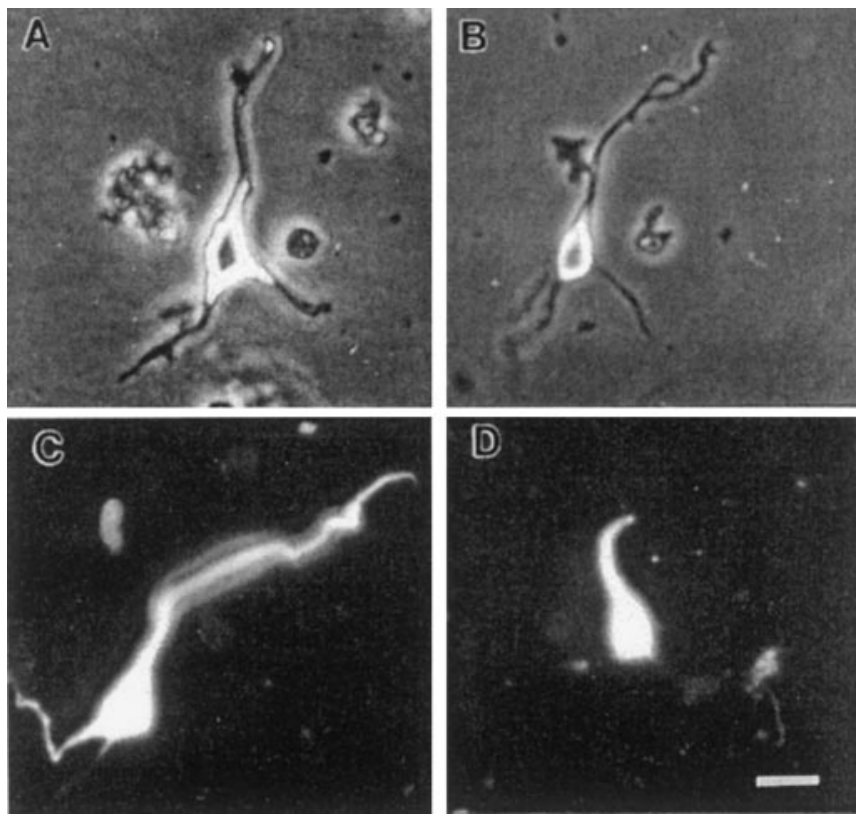

Figure 1. Photomicrographs of dissociated amygdala cells. $A$ and $B$ are phase-contrast photomicrographs. $C$ and $D$ are fluorescence micrographs showing immunochemical labeling for neuron-specific enolase. $A$ and $C$ show the larger putative AHA projection neurons. $B$ and $D$ show examples of smaller cells. Scale bar: $A-D, 15 \mu \mathrm{m}$.

the patch pipette at a uniform concentration. In a few experiments, glucose was completely omitted from the external superfusion solution, and the osmolarity was $325 \mathrm{mOsmol} / \mathrm{kg}$; when glucose and sucrose were both completely omitted, osmolarity was $300 \mathrm{mOsmol} / \mathrm{kg}$. One patch was tested per cell. All drugs were obtained from Sigma. Data were collected and analyzed with an Axopatch-1D recording system and pClamp software (Axon Instruments, Foster City, CA), with filtering at $2 \mathrm{kHz}$ lowpass and digital acquisition at $100 \mu \mathrm{sec} /$ point. Inward single-channel currents are shown in figures as upward deflections, and membrane potential is expressed relative to cell resting potential. Because cellattached recordings were performed with approximately symmetrical concentrations $(140 \mathrm{~mm})$ of $\mathrm{K}^{+}$across the patch membrane, the reversal potential of a $\mathrm{K}^{+}$-permeable channel should occur when the patch is depolarized by an amount equal to the resting membrane potential of the cell. In every cell-attached recording we varied the electrode potential to determine the apparent reversal potential of any channels that were expressed. In recordings from phase-bright cells, the resting membrane potential thus inferred consistently fell between -40 and $-70 \mathrm{mV}$, with most cells at -50 to $-55 \mathrm{mV}$, whereas phase-dark cells were significantly more depolarized, and these results were confirmed by direct measurements of membrane potential in perforated-patch recordings. Except where stated otherwise, all cell-attached recordings were from cells negative to $-40 \mathrm{mV}$, with seal resistance $>5 \mathrm{G} \Omega$, and preservation of these parameters and of phase-bright morphology for the duration of the recording of not $<10 \mathrm{~min}$. Records in figures are at resting potential unless otherwise stated. All data are expressed as mean $\pm \mathrm{SD}$, and all statistical comparisons were performed by a $t$ test, unless otherwise stated. All-points amplitude histograms were used to determine the fractional open probability $P_{o}$, as $1-N P_{c}$, where $N$ was the number of active channels in the patch (determined from the number of peaks) and $P_{c}$ was the fraction of time that no current was passed. Current amplitudes for determinations of channel conductance were determined from peak-to-peak distances of amplitude histograms.

\section{RESULTS}

\section{Cellular identification}

The dissociated cell preparation yielded a variety of cellular morphologies when viewed under phase-contrast optics. Some cells had diameters of $\sim 30-40 \mu \mathrm{m}$ and were multipolar or pyramidal in shape (Fig. $1 A$ ). Others ranged between 5 and $20 \mu \mathrm{m}$ and 
had a variety of shapes, but were frequently unipolar or bipolar (Fig. $1 B$ ), and represented the majority of cells in the preparation. Cells of intermediate sizes were not encountered. Cells of both morphologies were immunoreactive for neuron-specific enolase (Fig. $1 C, D$ ). Among the $30-40 \mu \mathrm{m}$ cells, 31 of 32 observed (97\%) were immunoreactive, as were 365 of 420 of the smaller cells $(87 \%)$; no nonspecific labeling was observed in either cell group when the primary antibody was omitted from the incubation. In contrast, no labeling for glial fibrillary acidic protein was seen in 12 of the larger cells and 158 of the smaller cells, although the same antibody gives positive labeling of some dissociated cells from the caudate-putamen in our hands (Greif et al., 1995). Thus, a large proportion of the dissociated amygdala cells were neurons.

We used amygdala slices comprising the AHA as well as some regions immediately ventral to it, principally the cortical nucleus of the amygdala, when preparing the dissociated cells, and so it is probable that our preparation included cells from both areas. Others have shown that the principal projection neurons of the AHA are 30-40 $\mu \mathrm{m}$ pyramidal or spindle-shaped cells, whereas neurons from adjacent areas are smaller (Krettek and Price, 1978). We therefore tested whether the larger cells in our preparation might arise from the AHA. When we labeled intact slices of posteriodorsomedial amygdala for $\mu$ opioid receptors, there was extensive cellular labeling in the AHA, but sparse labeling in the more ventral areas (Fig. $2 A$ ). When viewed at higher magnification, cells labeled for $\mu$ receptors in the slices had morphologies consistent with AHA projection neurons (Fig. 2B) and closely resembled dissociated cells that were similarly labeled (Fig. 2C). The neuropeptide galanin is known to be a marker for some projection neurons in the AHA and regions immediately rostral to it (Planas et al., 1994). In intact unfixed slices, galanin immunoreactivity was found in cells within the AHA closely resembling the cells that were labeled for $\mu$ receptors (Fig. 2D).

In populations of dissociated cells (Table 1$), \mu$ receptor immunoreactivity was expressed by a large percentage of the $30-40 \mu \mathrm{m}$ cells, as shown in Figure $2 C$, but was much less prevalent in the 5-20 $\mu \mathrm{m}$ cells. Far fewer cells were labeled for $\delta$ receptors than for $\mu$ receptors, and we obtained only negative results in labeling for $\kappa$ receptors (Table 1 ). Taken together, these results indicate that the 30-40 $\mu \mathrm{m}$ dissociated cells are mostly projection neurons from the AHA and tend to express $\mu$ receptor immunoreactivity, whereas the 5-20 $\mu \mathrm{m}$ cells represent other types of cells present in our preparation, arising largely from adjacent areas of the amygdala.

\section{Effects of opioid receptor activation}

We performed perforated-patch and cell-attached patch recordings from these dissociated cells. In whole-cell current-clamp recordings using perforated-patch, the 30-40 $\mu \mathrm{m}$ cells responded to the opioid peptide met-enkephalin $(10-20 \mu \mathrm{M})$ with a hyperpolarization (Fig. $3 A$ ), consistent with the known inhibitory response of AHA cells to this compound in vivo (Freedman and Aghajanian, 1985). With a prolonged application, the response was stable for $\sim 1 \mathrm{~min}$, after which there was a progressive decline in the amplitude of the response, consistent with some desensitization, but the response to enkephalin was rapidly restored and repeatable after washout (Fig. $3 A$ ). The maximal amplitude of the hyperpolarization was $3.4 \pm 2.1 \mathrm{mV}(n=36$ trials on 15 cells $)$ and rarely went all the way to the $\mathrm{K}^{+}$reversal potential. Previous studies (Chen et al., 2000) showed that this effect was associated with a greater latency to the onset of action potentials, but did not
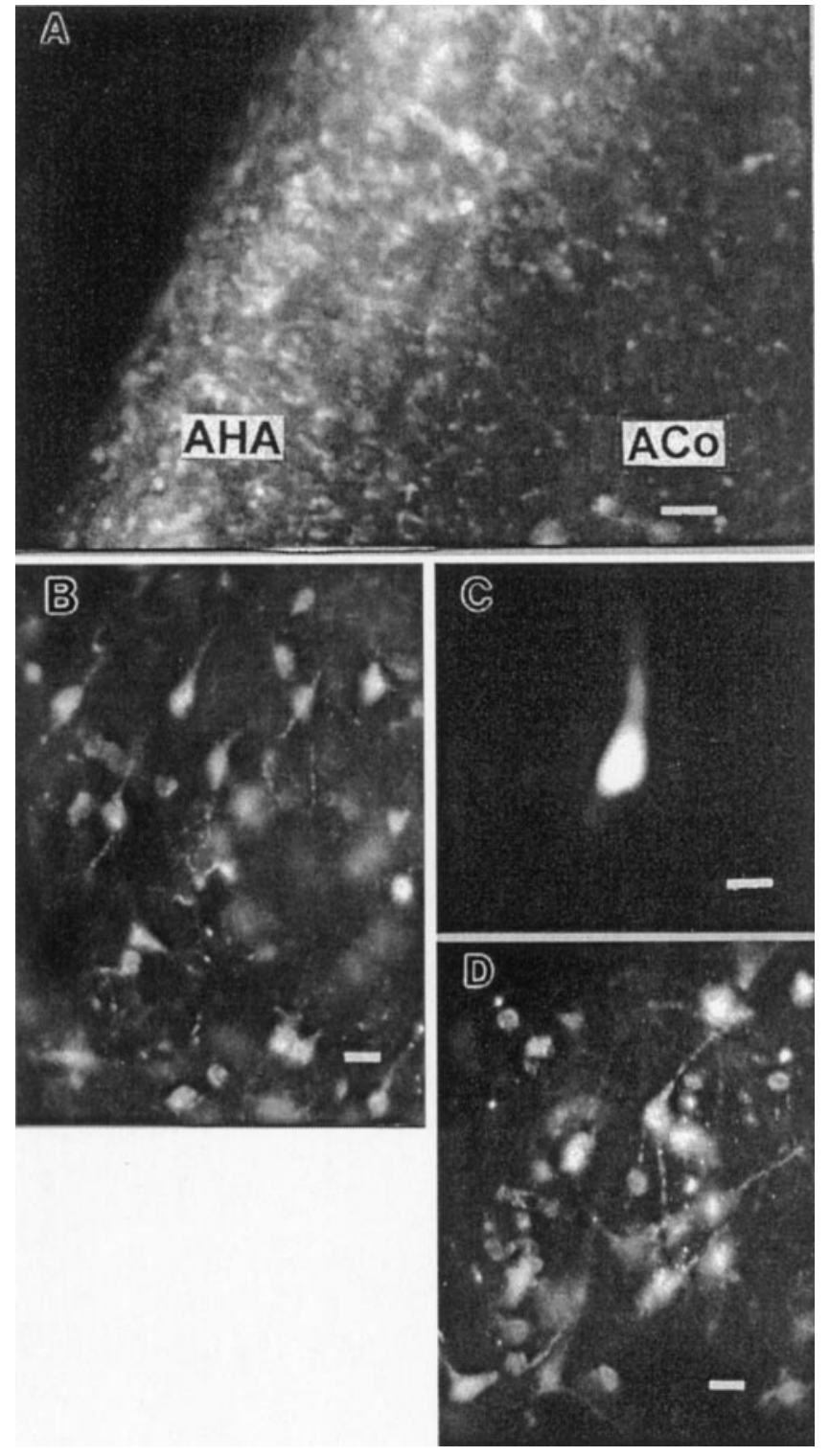

Figure 2. Fluorescence photomicrographs showing immunocytochemical characterization of amygdala cells. $A$, Low-power view of an intact fixed amygdala slice, labeled for $\mu$ opioid receptors, showing extensive labeling in the amygdalohippocampal area $(A H A)$ and sparse labeling in the cortical nucleus of the amygdala $(A C o)$. The left side of the AHA is the dorsal edge of the slice, where the ventral hippocampus was removed. Scale bar, $100 \mu \mathrm{m}$. $B$, Higher power view of the slice in $A$. Scale bar, 35 $\mu \mathrm{m}$. $C$, A dissociated cell, labeled for $\mu$ opioid receptors. Scale bar, $15 \mu \mathrm{m}$. $D$, An unfixed slice, within the AHA, labeled for galanin. Scale bar, $30 \mu \mathrm{m}$.

cause an obvious change in action potential properties. At low concentrations (5-25 $\mathrm{nm}$ ), the highly potent and selective $\mu$-opioid peptide endomorphin-1 (Zadina et al., 1997) elicited responses similar to those for met-enkephalin (Fig. $3 B)(n=6$ trials on four cells). In contrast, the same compound at concentrations higher than those selective for $\mu$ receptors $(>1 \mu \mathrm{M})$ elicited prominent depolarizations $(11.5 \pm 3.8 \mathrm{mV} ; n=8$ trials on four cells) (Fig. 3C).

As previously reported (Chen et al., 2000), a 130 pS channel was observed when met-enkephalin, endomorphin-1, or morphine were applied from within the patch pipette. Figure $4 A$ shows examples of channel recordings, with $130 \mathrm{pS}$ channel activity in the presence of agonists, but no activity in the absence of 


\begin{tabular}{|c|c|c|}
\hline Receptor subtype & Cells observed & Cells labeled (\%) \\
\hline \multicolumn{3}{|l|}{ Cells $30-40 \mu \mathrm{m}$} \\
\hline$\mu$ & 58 & $53(91)$ \\
\hline$\delta$ & 71 & $5(7)$ \\
\hline$\kappa$ & 26 & $0(0)$ \\
\hline Control $^{a}$ & 12 & $0(0)$ \\
\hline \multicolumn{3}{|l|}{ Cells 5-20 $\mu \mathrm{m}$} \\
\hline$\mu$ & 812 & $31(4)$ \\
\hline$\delta$ & 672 & $39(6)$ \\
\hline$\kappa$ & 280 & $0(0)$ \\
\hline Control $^{a}$ & 128 & $0(0)$ \\
\hline
\end{tabular}

${ }^{a}$ The primary antibody was omitted in control experiments.

\section{A}
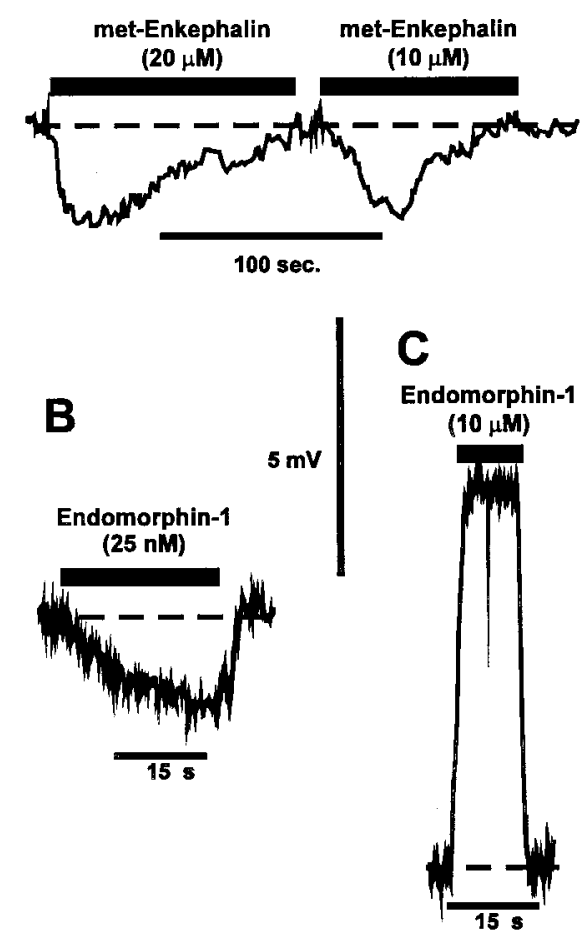

Figure 3. Perforated-patch recordings of whole-cell membrane potential in dissociated $30-40 \mu \mathrm{m}$ amygdala neurons. The heavy bars indicate the periods of application of the indicated drugs. The dashed lines indicate resting membrane potential, which was -45 to $-65 \mathrm{mV}$ in most cells. Scale bar: $A-C, 5 \mathrm{mV}$. $A$, Hyperpolarizing response to met-enkephalin, 20 $\mu \mathrm{M}$, followed by washout and reapplication at $10 \mu \mathrm{M}$. $B$, Hyperpolarizing response to a low concentration (25 nM) of endomorphin-1. $C$, Depolarizing response to a high concentration $(10 \mu \mathrm{M})$ of endomorphin-1.

drug, or when the relatively nonselective opiate antagonist naloxone or the $\mu$-selective antagonist D-Phe-Cys-Tyr-D-Trp-OrnThr-Pen-Thr-NH $\mathrm{H}_{2}$ (CTOP) (Gulya et al., 1986) were present with the agonists. This pattern of channel activity was maintained in a statistically significant manner when populations of cells were tested (Table 2). In addition, we have previously shown that channel activation occurred directly when agonists were applied by back-filling and that channel open probability increased as a function of agonist concentration (Chen et al., 2000). Thus, it appears clear that channel activation was receptor-mediated. A
A
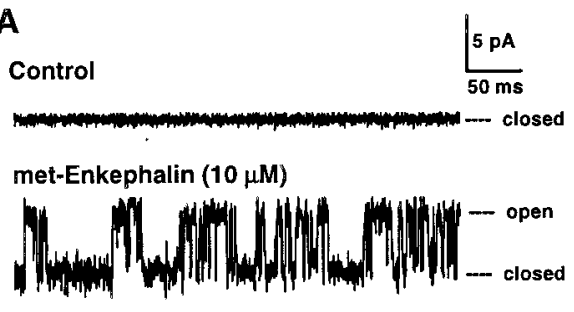

met-Enkephalin $(10 \mu \mathrm{M})+$ Naloxone $(1 \mu \mathrm{M})$

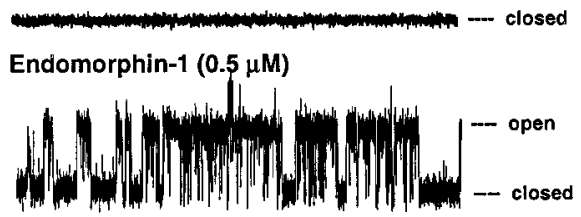

Endomorphin-1 (0.5 $\mu \mathrm{M})+$ CTOP $(0.1 \mu \mathrm{M})$

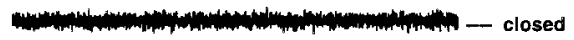

B
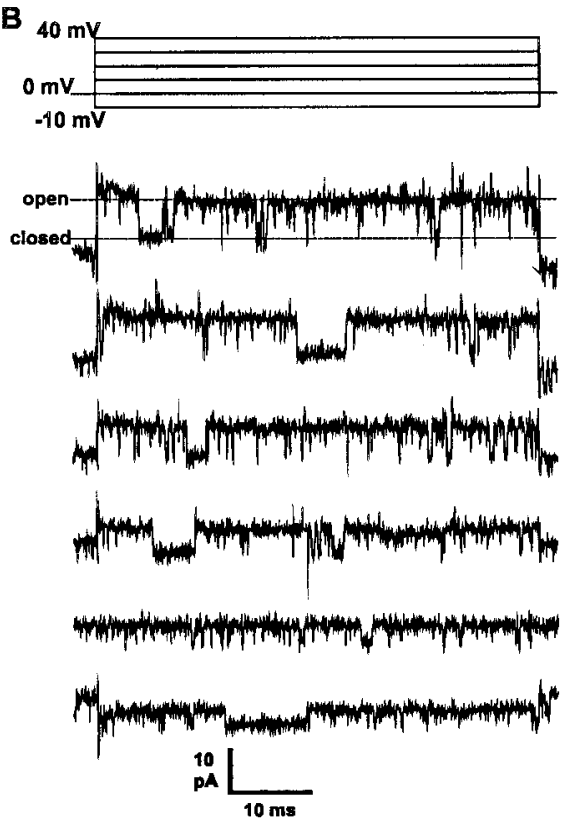

C

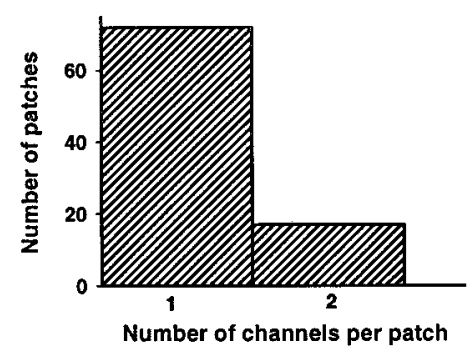

Figure 4. Single channel cell-attached patch recordings of the $130 \mathrm{pS}$ channel. $A$, Representative examples of recordings with various drugs in the patch pipette, showing channel activity in the presence of metenkephalin or endomorphin-1, and the absence of openings in control (no drug) recordings or when antagonists were present. $B$, Voltage insensitivity of channel openings at voltages negative to the reversal potential. Recordings from a single patch, with $10 \mu \mathrm{M}$ met-enkephalin in the patch pipette, under the voltage protocol shown at the top; pipette voltages are indicated. $C$, Distribution of the number of $130 \mathrm{pS}$ channels per patch. Patches with no channel openings are excluded from the figure. 


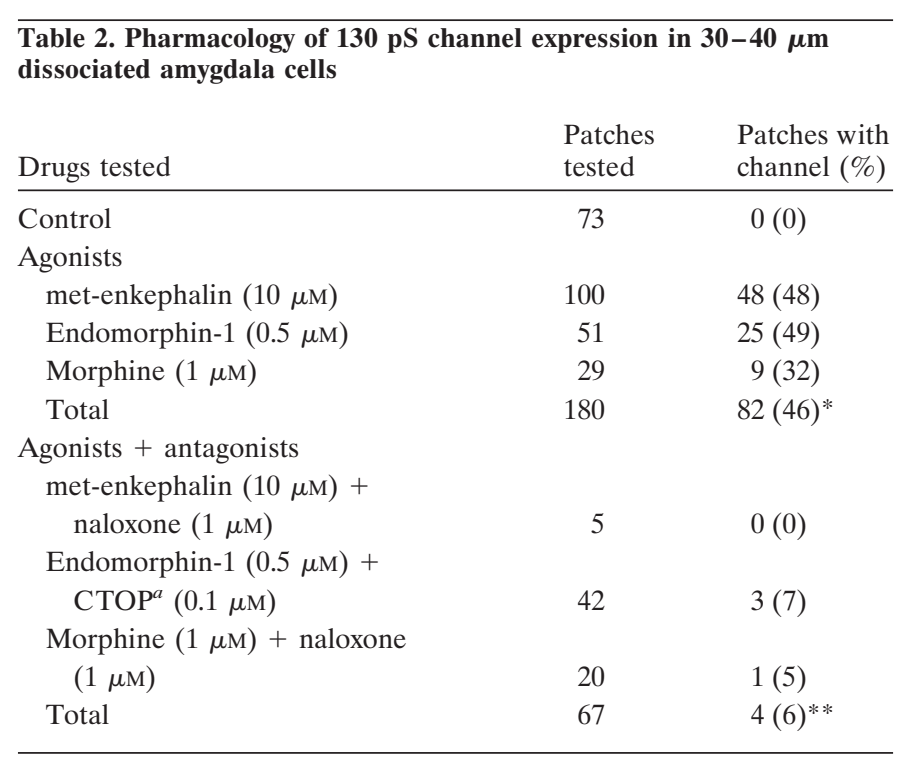

${ }^{a}$ CTOP, D-phe-cys-tyr-D-trp-orn-thr-pen-thr- $\mathrm{NH}_{2}$. ${ }^{*} p<0.001$ versus control.

$* * p<0.01$ versus total agonists.

comparison of the effects of $\mu, \delta$, and $\kappa$-selective agonists and antagonists indicated that channel activation was mediated principally by $\mu$ receptors (Chen et al., 2000), consistent with the selective expression of $\mu$ receptor immunoreactivity by these cells.

The channel was inwardly rectifying and otherwise showed no obvious voltage-dependence. At voltages negative to the reversal potential, the channel carried inward currents, and open probability did not appear to vary with membrane potential (Fig. 4B). Outward currents at voltages positive to the reversal potential were not observed, consistent with strong inward rectification. Open probability did not vary over time during a recording, and we saw no evidence of a time-dependent decrease in channel opening paralleling the decrease in the hyperpolarization observed in perforated-patch recordings (Fig. $3 A$ ).

At appropriate agonist concentrations, $130 \mathrm{pS}$ channel activity was observed in approximately half of recordings from the 30-40 $\mu \mathrm{m}$ cells (Table 2 ). Because one does not expect every patch to contain a channel molecule, it is probable that the $130 \mathrm{pS}$ channel was expressed by a large percentage of these cells. Using patch electrodes with tip diameters close to $1 \mu \mathrm{m}$, we consistently encountered one or two active channels per patch (Fig. 4C). This result contrasts with observations of an $85 \mathrm{pS}$ dopaminemodulated channel in caudate-putamen neurons, where we typically find two to four channels per patch under equivalent conditions (Greif et al., 1995). Consequently, there may be differences in channel or receptor distributions over the surface of the cell membrane between these two systems. When we instead recorded from the 5-20 $\mu \mathrm{m}$ diameter cells, we found no evidence for $130 \mathrm{pS}$ channel expression or activation (Table 3). Thus, the opioid-modulated $130 \mathrm{pS}$ channel appears to be expressed selectively by the AHA projection neurons and not by neurons from immediately adjacent areas of the amygdala.

\section{Other channels}

With $140 \mathrm{~mm} \mathrm{KCl}$ as the major component of the patch electrode solution, a large number of distinct single channels could be resolved in cell-attached recordings from these amygdala neurons, of which the $130 \mathrm{pS}$ channel was only one. In recordings
Table 3. Absence of $130 \mathrm{pS}$ channel expression in 5-20 $\mu \mathrm{m}$ dissociated amygdala cells

\begin{tabular}{lll} 
Drugs tested & $\begin{array}{l}\text { Patches } \\
\text { tested }\end{array}$ & $\begin{array}{l}\text { Patches with } \\
\text { channel }(\%)\end{array}$ \\
\hline Control & 27 & $0(0)$ \\
Agonists & & \\
$\quad$ met-enkephalin $(10 \mu \mathrm{M})$ & 34 & $0(0)$ \\
$\quad$ Endomorphin-1 $(0.5 \mu \mathrm{M})$ & 24 & $0(0)$ \\
Total & 58 & $0(0)^{*}$ \\
\hline$p<0.001$ versus "total agonists" in Table 2. &
\end{tabular}

from the 30-40 $\mu \mathrm{m}$ cells, we observed only inward currents with reversal potentials occurring when the patch was depolarized by an amount corresponding to resting membrane potentials observed in perforated-patch recordings, consistent with $\mathrm{K}^{+}$as the charge carrier under these conditions. Examples of some of these channels, recorded in the absence of drugs, are shown in Figure 5 . There were inwardly rectifying channels with conductances ranging between 20 and $100 \mathrm{pS}$ (Fig. 5A). At voltages negative to the reversal potential, these channels were not depolarizationdependent in their open probabilities. They thus resembled the dopamine receptor-insensitive inward rectifier channels in the caudate-putamen (Greif et al., 1995) except that they included channels of larger conductances. There were also channels of 150-200 pS, whose open probabilities increased conspicuously as the patch membrane was depolarized (Fig. $5 B$ ). These channels very much resemble large-conductance $\mathrm{Ca}^{2+}$-activated $\mathrm{K}^{+}$channels, although we have not characterized their $\mathrm{Ca}^{2+}$ sensitivities. There appeared to be a large number of values of conductances of both these groups of channels, reflecting their heterogeneity, and they appeared to be spontaneously active in the absence of applied agonists. Their conductances, determined from currentvoltage relationships, did not include values close to $130 \mathrm{pS}$ (Fig. $5 C$ ). We also observed channels appearing to be $\mathrm{Cl}^{-}$channels in a small percentage of recordings from the 5-20 $\mu \mathrm{m}$ cells, but these were not observed in the $30-40 \mu \mathrm{m}$ cells.

In a large number of recordings from the 30-40 $\mu \mathrm{m}$ cells, these various channels, but not the $130 \mathrm{pS}$ channel, could be observed in the absence of opiate agonists (Fig. 6A). When agonists were present within the patch pipette, all channel activities with conductances between 125 and $135 \mathrm{pS}$ behaved as a single population of conductance values, $130 \pm 2.8 \mathrm{pS}(n=35)$, normally distributed with a single mode (Kolmogorov-Smirnov normality test). There is consequently no evidence for more than one channel type with a conductance near $130 \mathrm{pS}$ in these cells. In comparisons of recordings in the presence or absence of opioid agonists, the agonist-dependent activation of this $130 \mathrm{pS}$ channel was by far the most conspicuous effect, although smaller effects on some other channels cannot be ruled out (Fig. $6 A, B$ ). Therefore, the $130 \mathrm{pS}$ channel could be readily distinguished at the singlechannel level from the multiplicity of other channels expressed by these cells, by its conductance and lack of depolarizationdependent activation. The effect of $\mu$ opioid receptor activation was specific to the $130 \mathrm{pS}$ channel on these cells.

\section{Effects of metabolic depletion and tolbutamide}

The $130 \mathrm{pS}$ channel was not observed in the absence of opioids in recordings from phase-bright cells with resting membrane potentials (inferred from reversal potentials) negative to $-40 \mathrm{mV}$ (Fig. $6 A$ ). However, we occasionally recorded from cells that were 

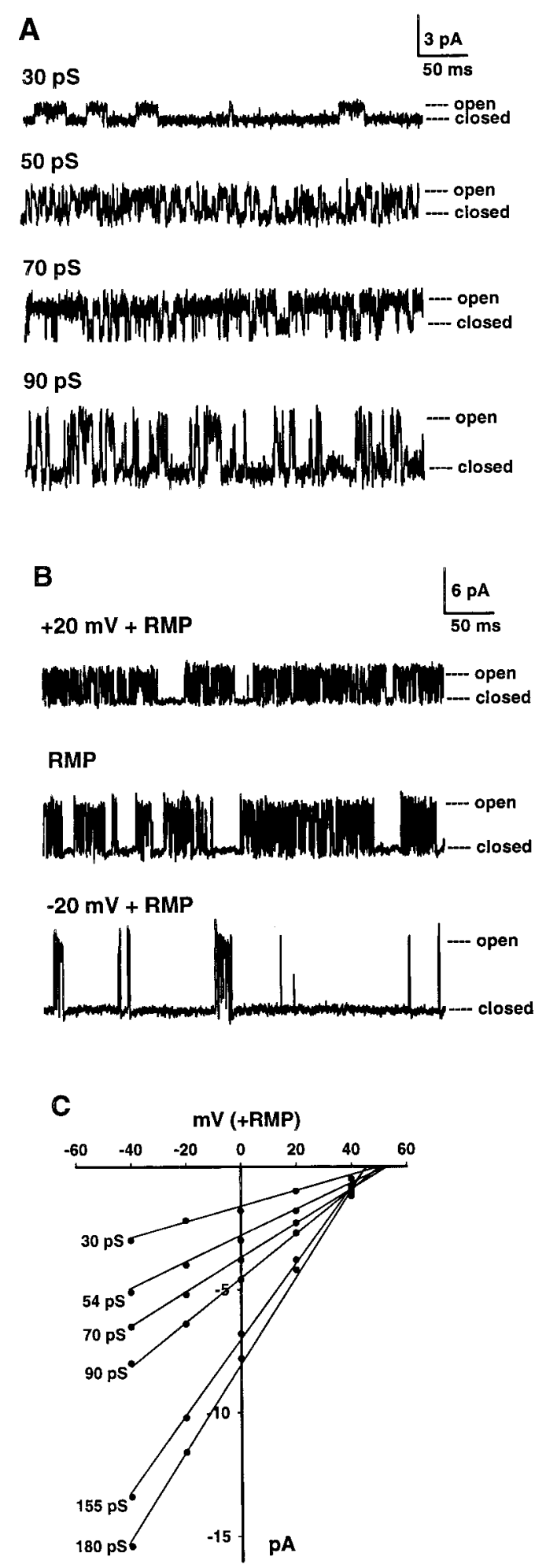

Figure 5. Other channels expressed by AHA neurons. A, Examples of smaller conductance inwardly rectifying channels, labeled by their conductances. Each record is at resting membrane potential. For these channels, outward currents could not be resolved at voltages positive to the reversal potential. $B$, A large-conductance $(186 \mathrm{pS})$ putative $\mathrm{Ca}^{2+}$-activated $\mathrm{K}^{+}$ channel, showing its voltage sensitivity. The patch was depolarized (top) or hyperpolarized (bottom) by $20 \mathrm{mV}$ from resting membrane potential $(R M P)$. C , Current-voltage relationships of various channels. Each plot is from a single experiment. The lines were fitted by linear regression of the points negative to the reversal potential (with nonzero inward currents), and the resulting slopes gave the indicated conductances.

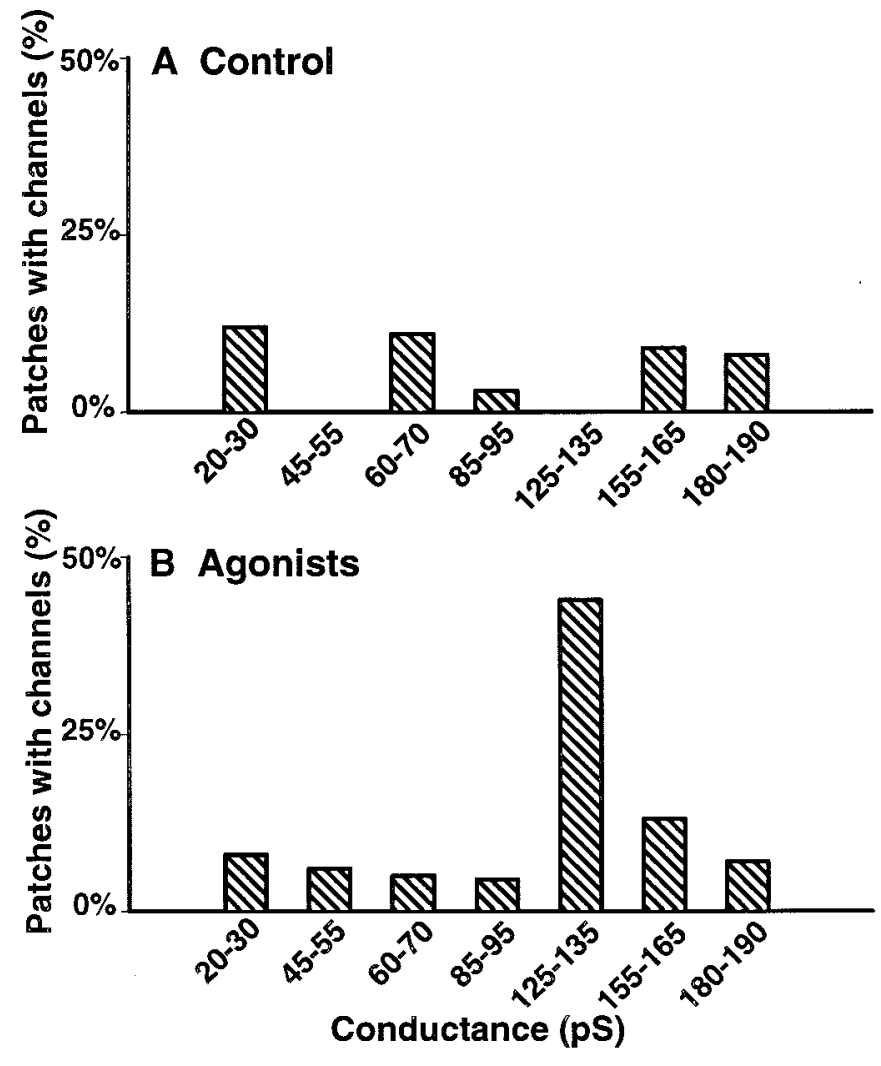

Figure 6. Percentages of all patches recorded from 30-40 $\mu \mathrm{m}$ amygdala cells expressing channel openings of various conductances. $A$, No drug present, 73 recordings. $B$, Pooled data from all recordings with metenkephalin, endomorphin-1, and morphine at all concentrations, 227 recordings. The number of patches expressing channels of a given conductance range are expressed as a percentage of all patches tested.

more depolarized, which we normally would not include in our data out of concern about cellular damage, and we observed spontaneous $130 \mathrm{pS}$ channel activity in some of these cells. Because channel activation was not depolarization-dependent (Fig. 4B), this observation suggests that the channel had been activated for some other reason, one possibility being metabolic depletion in a damaged cell. We tested this possibility by performing cell-attached recordings in the absence of opioid drugs, but with removal of glucose from the external medium. We first obtained cell-attached recordings with no drug present and verified the absence of $130 \mathrm{pS}$ openings in the patch. We then changed the external perfusion medium to one from which glucose was excluded. Of eight cells (30-40 $\mu \mathrm{m}$ diameter) for which we made this solution change, five patches $(62 \%)$ displayed channel openings resembling the $130 \mathrm{pS}$ channel with high open probability (Fig. 7A). In two of these cells, we removed sucrose as well as glucose, with no apparent difference in results. Openings occurred within 30-60 sec of the solution change. We were not able to reverse channel activation by restoring glucose because the dissociated cells were generally not stable long enough under these conditions.

We also recorded in the absence of opioids with the metabolic inhibitor rotenone $(5 \mu \mathrm{M})$ present continuously in the external superfusion solution. Rotenone is expected to reduce cytoplasmic levels of ATP (Ashcroft et al., 1985; Haworth et al., 1989), but does not otherwise interfere with the ability to record from these neurons. We observed $130 \mathrm{pS}$ channel activity in 10 of 23 record- 

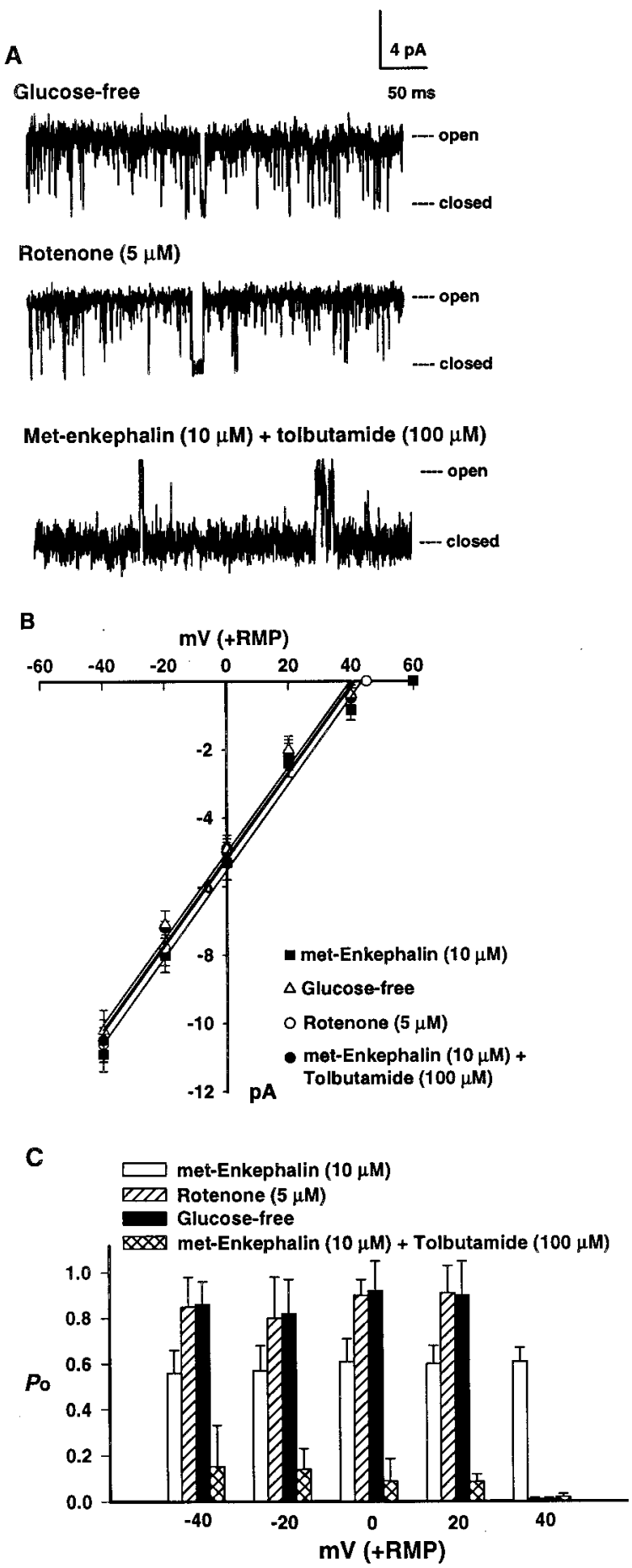

Figure 7. Metabolic activation and sulfonylurea inhibition of the $130 \mathrm{pS}$ channel. $A$, Single-channel recordings at resting potential. Top, Recording in the absence of opioid drugs, from a patch where we initially verified the absence of channel activity and then changed the external solution to one that was nominally glucose-free. Middle, Recording in the absence of opioid drugs, with $5 \mu \mathrm{M}$ rotenone applied in the bath solution surrounding the cell. Bottom, Recording with met-enkephalin $(10 \mu \mathrm{M})$ plus tolbutamide $(100 \mu \mathrm{M})$ present within the patch pipette. $B$, Current-voltage relationships for recordings with met-enkephalin $(10 \mu \mathrm{M}$ in the patch pipette) or the recording conditions in $A$. Membrane potential is expressed relative to RMP. At each point, $n=5-9$ patches. The lines were each fitted by linear regression as in Figure $5 C$, with slopes of $130 \pm 1 \mathrm{pS}$. $C$, Fractional channel open probability $P_{o}$ as a function of membrane potential; $n=5-9$. The rotenone and nominally glucose-free data reached the reversal potential when the patch was depolarized by $40 \mathrm{mV}$. ings $(43 \%)$ from $30-40 \mu \mathrm{m}$ cells under these conditions, a frequency similar to that found with opioid agonists. Again, channel openings were observed that closely resembled those obtained with removal of glucose (Fig. $7 A$ ).

As expected, rotenone-treated and glucose-depleted cells were slightly depolarized compared with control cells, as revealed by a shift in the reversal potential (Fig. 7B,C). However, the channel conductance of $130 \mathrm{pS}$ was unchanged from that obtained with opioids (Fig. 7B). At voltages negative to the reversal potential, the fractional open probability of the channel was somewhat greater for glucose depletion or rotenone treatment than for opioids, with near-complete channel opening (Fig. 7C). Otherwise, however, the inwardly rectifying behavior of the channel was the same. It thus appears that the same channel could be activated in the absence of opioid agonists, under conditions of reduced concentrations of intracellular ATP.

We also recorded with the sulfonylurea drug tolbutamide (100 $\mu \mathrm{M})$ present within the patch pipette along with met-enkephalin. When $130 \mathrm{pS}$ channel openings were present ( $n=9$ cells), openings were much briefer than was observed with metenkephalin alone (Fig. 7A). Fractional channel open probability was markedly reduced (Fig. $7 C$ ), consistent with inhibition of channel gating. However, there was once again no difference in the $130 \mathrm{pS}$ conductance of the channel (Fig. $7 B$ ). Thus, the same channel activated by opioid receptors also displayed the metabolic sensitivity and sulfonylurea inhibition associated with $\mathrm{K}_{\mathrm{ATP}}$ channels.

\section{DISCUSSION}

\section{The $130 \mathrm{pS}$ channel}

The major findings of our study are that the $\mu$ receptor-activated $130 \mathrm{pS}$ channel is expressed selectively by the projection neurons of the AHA, that, of the multiple $\mathrm{K}^{+}$-permeable channels expressed by these cells, $\mu$ receptor activation is selective for this channel, and that this same channel can be activated in the absence of $\mu$ agonists under conditions of metabolic depletion. AHA neurons are known to consistently express inhibitory responses to $\mu$ agonists in vivo (Freedman and Aghajanian, 1985). We found that low concentrations of $\mu$ agonists also elicited hyperpolarizing responses in these cells (Fig. $3 A, B$ ). Although high concentrations of endomorphin-1 could also depolarize these cells (Fig. 3C), this effect occurred at concentrations approximately three orders of magnitude higher. The lower endomorphin-1 concentrations, which hyperpolarized the cells and activated the channel, corresponded closely with those selective for $\mu$ receptors (Zadina et al., 1997), whereas the depolarizing concentrations were far higher. We therefore believe that the hyperpolarization seen at lower concentrations is more likely to be the receptor response, and the depolarization is likely to be a nonspecific effect of this compound. We previously found that the $130 \mathrm{pS}$ channel can carry both $\mathrm{K}^{+}$and $\mathrm{Na}^{+}$, but is selective for $\mathrm{K}^{+}$over $\mathrm{Na}^{+}$(Chen et al., 2000). The fact that the hyperpolarizations observed here did not reach the $\mathrm{K}^{+}$reversal potential is consistent with a mixed-ion mechanism. Therefore, the $130 \mathrm{pS}$ channel could contribute significantly to the whole-cell response, although our data certainly do not rule out $\mu$ receptor effects on other channels in these cells. The apparent desensitization observed at the whole-cell level (Fig. $3 A$ ) was not observed at the single-channel level, and is clearly distinct from the gating change of this channel that may accompany tolerance after chronic morphine treatment (Chen et al., 2000). The absence of desensitization in cell-attached recordings might result from the limited 
exposure of the cell surface that occurs when the agonist is only present within the patch pipette, whereas the entire cell membrane is exposed to the agonist in whole-cell recordings.

Channels activated by glucose depletion or by rotenone and those activated by $\mu$ agonists were remarkably similar. The only difference appears to be a somewhat higher open probability seen with metabolic depletion, which could reflect different mechanisms of channel modulation. Because no other channels of 130 $\mathrm{pS}$ conductance were found under control conditions, it is very likely that the same channel was activated in each case. We have not, however, been able to show that internal ATP gates the channel, because this channel proved unstable in inside-out recordings. However, our results are very similar to those for the 85 pS channel modulated by $\mathrm{D}_{2}$ dopamine receptors in caudateputamen neurons (Greif et al., 1995). That channel is also activated by rotenone, is sensitive to sulfonylurea drugs in a manner suggestive of a $\mathrm{K}_{\mathrm{ATP}}$ channel (Lin et al., 1993), and has recently been shown to be directly regulated by ATP (Sun et al., 2000). However, our tolbutamide data reveal one interesting difference between these channels. The $85 \mathrm{pS}$ channel could be largely inhibited by submicromolar concentrations of this drug (Lin et al., 1993), whereas concentrations of $\sim 100 \mu \mathrm{M}$ were needed to give the same effect for the $130 \mathrm{pS}$ channel (Fig. 7), more like most $\mathrm{K}_{\text {ATP }}$ channels (Freedman and Lin, 1996). This finding suggests that different sulfonylurea-binding proteins may be involved in the two systems.

The $130 \mathrm{pS}$ channel has a number of distinctive properties. Based on its conductance, it is clearly not the same as the inwardly rectifying $30-45 \mathrm{pS} \mathrm{K}^{+}$channel activated by $\mu$ receptors in the locus coeruleus (Miyake et al., 1989; Grigg et al., 1996). However, because $130 \mathrm{pS}$ channel activation is membrane-delimited (Chen et al., 2000), it is likely to be activated either by direct binding of G-protein $\beta \gamma$ subunits (Slesinger et al., 1995) or by their action via a sulfonylurea-binding protein (Wada et al., 2000). Its relative permeability for $\mathrm{K}^{+}$and $\mathrm{Na}^{+}$is similar to the opioid-sensitive $I_{\mathrm{h}}$ current (Svoboda and Lupica, 1998), but it is not sensitive to cyclic nucleotides (Chen et al., 2000), and it has no voltage sensitivity in its activation. It also somewhat resembles the cation channel modulated by $\mu$ receptors in the locus coeruleus (Alreja and Aghajanian, 1993), but is more $\mathrm{K}^{+}$-selective and appears likely to contribute to a hyperpolarizing rather than a depolarizing response. Finally, it has some of the properties of a $\mathrm{K}_{\mathrm{ATP}}$ channel, or at least is metabolically sensitive and inhibited by sulfonylureas.

\section{Functional implications}

Our data are limited by the facts that we have used populations of cell-attached recordings to characterize the receptor modulation of channels and that we did not immunocytochemically label the same cells that we recorded electrophysiologically. However, it can be concluded that $\mu$ receptors do activate this channel and that it is expressed by many of the AHA projection neurons. What might be its functional significance in the amygdala?

The amygdala contributes to the motivational aspects of opiate drug dependence (Koob et al., 1992), and amygdala lesions suppress some opiate withdrawal signs (Calvino et al., 1979). The amygdala is activated in human addicts during drug craving (Breiter and Rosen, 1999). Within the amygdala, the AHA is one of two regions that express functional inhibitory responses to $\mu$ agonists in vivo (Freedman and Aghajanian, 1985). There is also evidence for a role of the AHA and regions immediately rostral to it, through which AHA efferent fibers pass (Maragos et al.,
1989), in sexual behaviors. This part of the amygdala is innervated by the accessory olfactory bulb, which in turn receives inputs from the vomeronasal organ and thus might respond to pheromones (Demas et al., 1997; Martinez-Marcos and Halpern, 1999; Petrulis and Johnston, 1999). The AHA projects to areas of the hypothalamus thought to regulate sexual behaviors (Pitkanen et al., 1997; Swanson and Petrovich, 1998). This pathway is activated by sexual anticipation (Kondo et al., 1997), which might be considered to have some resemblance to craving, and lesions of this pathway disrupt sexual behaviors (Heeb and Yahr, 2000). Thus, opioid receptor activation leading to an inhibition of AHA cell firing, partly through the $130 \mathrm{pS}$ channel, might be able to decrease some components of sexual craving and thus contribute in part to opiate drug reward.

There is also evidence for a role of the AHA and adjacent areas in feeding and satiety. At least some of the neurons expressing the $130 \mathrm{pS}$ channel contain galanin as a neurotransmitter (Fig. $2 D)$, and the regulation of galanin release in the amygdala is expected to affect feeding behavior (Krykouli et al., 1990). Lesions near this area affect feeding and satiety (Rollins and King, 2000). In primates, some amygdala neurons are glucose-sensitive in their firing, and so can sense brain glucose levels (Raggozino and Gold, 1994; Yan and Scott, 1996). Because the 130 pS channel is metabolically sensitive, it can contribute to the ability of AHA neurons to respond to changes in glucose. Animal studies indicate that craving for opiate drugs varies with hunger or satiety (Shalev et al., 2001). Because opioids modulate the $130 \mathrm{pS}$ channel, there thus could be an interaction between opiate craving and food craving. We found that metabolic depletion could activate the 130 pS channel to near-100\% opening (Fig. $7 C$ ), such that there would be little additional possible activation by opiates. Perhaps in a hungry subject the $130 \mathrm{pS}$ channel would already be activated, and so the neurons would be less responsive to opioid neurotransmission, thus reducing the salience of other types of cravings. Whether this is true will require further studies, but our results clearly show that a specific channel molecule is modulated both by opioids and by metabolism in this limbic brain region.

\section{REFERENCES}

Alreja M, Aghajanian GK (1993) Opiates suppress a resting sodiumdependent inward current in addition to activating an outward potassium current in locus coeruleus neurons. J Neurosci 13:3525-3532.

Ashcroft FM, Ashcroft SJH, Harrison DE (1985) The glucose-sensitive potassium channel in rat pancreatic beta-cells is inhibited by intracellular ATP. J Physiol (Lond) 369:101.

Breiter HC, Rosen BR (1999) Functional magnetic resonance imaging of brain reward circuitry in the human. Ann NY Acad Sci 877:523-547.

Calvino B, Lagowska J, Ben-Ari Y (1979) Morphine withdrawal syndrome: differential participation of structures located within the amygdaloid complex and striatum of the rat. Brain Res 177:19-34.

Chen X, Marrero HG, Murphy R, Lin Y-J, Freedman JE (2000) Altered gating of opiate receptor-modulated $\mathrm{K}^{+}$channels on amygdala neurons of morphine-dependent rats. Proc Natl Acad Sci USA 97:14692-14696.

Demas GE, Williams JM, Nelson RJ (1997) Amygdala but not hippocampal lesions impair olfactory memory for mate in prairie voles (Microtus ochrogaster). Am J Physiol 273:R1638-R1689.

Freedman JE, Aghajanian GK (1985) Opiate and $\alpha_{2}$-adrenoceptor responses of rat amygdaloid neurons: co-localization and interactions during withdrawal. J Neurosci 5:3016-3024.

Freedman JE, Lin Y-J (1996) ATP-sensitive potassium channels: diverse functions in the central nervous system. The Neuroscientist 2:145-152

Greif GJ, Lin Y-J, Liu J-C, Freedman JE (1995) Dopamine-modulated potassium channels on rat striatal neurons: specific activation and cellular expression. J Neurosci 15:4533-4544.

Grigg JJ, Kozasa T, Nakajima Y, Nakajima S (1996) Single-channel properties of a G-protein-coupled inward rectifier potassium channel in brain neurons. J Neurophysiol 75:318-328.

Gulya K, Pelton JT, Hruby VJ, Yamamura HI (1986) Cyclic somatostatin octapeptide analogues with high affinity and selectivity toward mu opioid receptors. Life Sci 38:2221-2229. 
Haworth RA, Goknur AB, Berkoff HA (1989) Inhibition of ATP sensitive potassium channels of adult rat heart cells by antiarrhythmic drugs. Circ Res 65:1157-1160.

Heeb MM, Yahr P (2000) Cell-body lesions of the posterodorsal preoptic nucleus or posterodorsal medial amygdala, but not the parvicellular subparafascicular thalamus, disrupt mating in male gerbils. Physiol Behav 68:317-331.

Kang YM, Hu WM, Qiao JT (1998) Endogenous opioids and ATPsensitive potassium channels are involved in the mediation of apomorphine-induced antinociception at the spinal level: a behavioral study in rats. Brain Res Bull 46:225-228.

Kondo Y, Sachs BD, Sakuma Y (1997) Importance of the medial amygdala in rat penile erection evoked by remote stimuli from estrous females. Behav Brain Res 88:153-160.

Konig JFR, Klippel RA (1963) The rat brain: a stereotaxic atlas of the forebrain and lower parts of the brain stem. Huntington, NY: RE Krieger.

Koob GF, Maldonado R, Stinus L (1992) Neural substrates of opiate withdrawal. Trends Neurosci 15:186-191.

Krettek JE, Price JL (1978) A description of the amygdaloid complex in the rat and cat with observations on intra-amygdaloid axonal connections. J Comp Neurol 178:255-280.

Krykouli SE, Stanley BG, Seirafi RD, Leibowitz SF (1990) Stimulation of feeding by galanin: anatomical localization and behavioral specificity of this peptide's effects in the brain. Peptides 11:995-1001.

Lin Y-J, Greif GJ, Freedman JE (1993) Multiple sulfonylurea-sensitive potassium channels: a novel subtype modulated by dopamine. Mol Pharmacol 44:907-910.

Lohmann AB, Welch SP (1999) Antisenses to opioid receptors attenuate ATP-gated $\mathrm{K}^{+}$channel opener-induced antinociception. Eur J Pharmacol 384:147-152.

Maragos WM, Newman SW, Lehman MN, Powers JB (1989) Neurons of origin and fiber trajectory of amygdalofugal projections to the medial preoptic area in Syrian hamsters. J Comp Neurol 280:59-71.

Martinez-Marcos A, Halpern M (1999) Differential projections from the anterior and posterior divisions of the accessory olfactory bulb to the medial amygdala in the opossum, Monodelphis domestica. Eur J Neurosci 11:3789-3799.

Miyake M, Christie M, North RA (1989) Single potassium channels opened by opioids in rat locus ceruleus neurons. Proc Natl Acad Sci USA 86:3419-3422.

Murphy R, Freedman JE (2001) Morphine and clonidine activate different $\mathrm{K}^{+}$channels on rat amygdala neurons. Eur $\mathrm{J}$ Pharmacol 415:R1-R3.

Ocana M, Delpozo E, Barrios M, Robles LI, Baeyens JM (1990) An ATP-dependent potassium channel blocker antagonizes morphine analgesia. Eur J Pharmacol 186:377-378.

Paxinos G, Watson C (1986) The rat brain in stereotaxic coordinates. San Diego, CA: Academic.

Petrulis A, Johnston RE (1999) Lesions centered on the medial amygdala impair scent-marking and scent-odor recognition but spare discrimination of individual odors in female golden hamsters. Behav Neurosci 113:345-357.
Pitkanen A, Savander V, Ledoux JE (1997) Organization of intraamygdaloid circuitries in the rat: an emerging framework for understanding functions of the amygdala. Trends Neurosci 20:517-523.

Planas B, Kolb PE, Raskind MA, Miller MA (1994) Galanin in the bed nucleus of the stria terminalis and medial amygdala of the rat: lack of sexual dimorphism despite regulation of gene expression across puberty. Endocrinol 134:1999-2004.

Raffa RB, Codd EE (1994) Lack of glibenclamide or TEA affinity for opioid receptors: further evidence for in vivo modulation of antinociception at $\mathrm{K}^{+}$channels. Brain Res 650:146-148.

Raggozino ME, Gold PE (1994) Task-dependent effects of intraamygdala morphine injections: attenuation by intra-amygdala glucose injections. J Neurosci 14:7478-7485.

Rhee J-S, Ebihara S, Akaike N (1994) Gramicidin perforated patchclamp technique reveals glycine-gated outward chloride current in dissociated nucleus solitarii neurons of the rat. $J$ Neurophysiol 72:1103-1108.

Rodrigues ARA, Duarte IDG (2000) The peripheral antinociceptive effect induced by morphine is associated with ATP-sensitive $\mathrm{K}^{+}$channels. Br J Pharmacol 129:110-114.

Rollins BL, King BM (2000) Amygdala-lesion obesity: what is the role of the various amygdaloid nuclei? Am J Physiol 279:R1348-R1356.

Seino S (1999) ATP-sensitive potassium channels: a model of heteromultimeric potassium channel/receptor assemblies. Annu Rev Physiol 61:337-362.

Shalev U, Yap J, Shaham Y (2001) Leptin attenuates acute food deprivation-induced relapse to heroin seeking. $J$ Neurosci 21:RC129:1-5.

Shankar V, Armstead WM (1995) Opioids contribute to hypoxiainduced pial artery dilation through activation of ATP-sensitive $\mathrm{K}^{+}$ channels. Am J Physiol 269:H997-H1002.

Slesinger PA, Reuveny E, Jan YN, Jan LY (1995) Identification of structural elements involved in $\mathrm{G}$ protein gating of the GIRK1 potassium channel. Neuron 15:1145-1156.

Sun X-D, Lee EW, Wong EH, Lee KS (2000) ATP-sensitive potassium channels in freshly dissociated adult rat striatal neurons: activation by metabolic inhibitors and the dopaminergic receptor agonist quinpirole. Pflügers Arch 440:530-547.

Svoboda KR, Lupica CR (1998) Opioid inhibition of hippocampal interneurons via modulation of potassium and hyperpolarization-activated cation $\left(I_{h}\right)$ currents. J Neurosci 18:7084-7098.

Swanson LW, Petrovich GD (1998) What is the amygdala? Trends Neurosci 21:323-331.

Wada Y, Yamashita T, Imai K, Miura R, Takao K, Nishi M, Takeshima H, Asano T, Morishita R, Nishizawa K, Kokubun S, Nukada T (2000) A region of the sulfonylurea receptor critical for a modulation of ATP-sensitive $\mathrm{K}^{+}$channels by G-protein $\beta \gamma$-subunits. EMBO J 19:4915-4925.

Yan JQ, Scott TR (1996) The effect of satiety on responses of gustatory neurons in the amygdala of alert cynomolgus macaques. Brain Res 740:193-200.

Zadina JE, Hackler L, Ge LJ, Kastin AJ (1997) A potent and selective endogenous agonist for the mu-opiate receptor. Nature 386:499-502. 